\title{
Effect of Streptozotocin on Erythrocyte and Retinal Superoxide Dismutase
}

\author{
R. Crouch, G. Kimsey, D. G. Priest, A. Sarda, and M. G. Buse \\ Departments of Biochemistry, Medicine and Ophthalmology, Medical University of South Carolina, Charleston, South Carolina, USA
}

Summary. The superoxide dismutase (SOD) activity of rat retinae and erythrocytes was decreased by $30-40 \%$ from control levels 5 days after the induction of diabetes with streptozotocin. Homogenates prepared from lungs, liver, brains, aortas, kidneys, whole eyes and lens of streptozotocin-diabetic rats showed no change in SOD activity. Treatment with insulin for three days which restored plasma glucose levels close to normal failed to affect retinal SOD activity in diabetic rats. Retinas (rat and bovine) and erythrocytes (human and rat) showed decreased SOD activity following in vitro incubation with streptozotocin. The need for careful differentiation of drug-induced from diabetes-induced effects in studies of experimental diabetes is reemphasized.

Key words: Superoxide dismutase, diabetes mellitus, streptozotocin, retina, erythrocytes.

Streptozotocin, an anti-tumour agent obtained from the fungus Streptomyces achromogenes, is widely used to produce diabetes in experimental animals [ 1 , $2]$. The drug destroys insulin secreting cells relatively selectively and is used in humans to treat inoperable cancer of $\beta$-cells.

The mode of action of streptozotocin on the $\beta$ cells is incompletely understood. The molecule consists of a glucosamine glucopyranose ring attached by the glucosamine nitrogen to a substituted nitrosourea group. It is possible that the glucose moiety permits binding of the molecule to glucose-receptors on cells which have such receptors, e.g., $\beta$-cells, while the nitrosourea group causes cell damage. Streptozotocin reduces islet NAD content in vivo [4] and in vitro [5]. Likewise the reduced glutathione of red blood cells is decreased [6]. Glucose, nicotinamide and epinephrine were found to protect against the latter effect. These results were interpreted to mean that streptozotocin exerts its cytotoxic effects through the oxidation of glutathione [6].

The enzyme superoxide dismutase (Superoxide oxidoreductase, ECl. 15.1.1) has been proposed as the primary defence against the superoxide radical $\left(\mathrm{O}_{2}^{-}\right.$, univalently reduced molecular oxygen) [7]. The physiological action of these radicals has been widely discussed and it appears that the $\mathrm{O}_{\dot{2}}$ radical, or hydroxyl radicals generated as a consequence of interaction with $\mathrm{H}_{2} \mathrm{O}_{2}$, may be important agents of oxygen toxicity. Hydrogen peroxide [8], hydroxyl radicals, and superoxide radicals [9] have all been found during the auto-oxidation of dialuric acid, a compound which also produces diabetes in rats by destroying the $\beta$-cells. These radicals have been implicated in the mechanism for the in vitro cytotoxicity of dialuric acid [10].

Evidence suggesting that the retina is susceptible to damage by oxygen radicals is found in the study of Chen and Patz [10] in which a proliferative retinopathy similar to the condition caused by diabetes was induced in puppies by exposure to hyperbaric oxygen. High concentrations of superoxide dismutase (SOD) are found in the retina $[11,12]$. The main retinal SOD isozyme has been shown to be identical to the erythrocyte enzyme $[12,13]$; however it has been clearly demonstrated that retinal SOD is not due to erythrocyte contamination [12, 13]. Our original intent was to determine if SOD is altered in the diabetic state by measuring the SOD levels of various tissues in normal and streptozotocin induced diabetic rats. The possibility that streptozotocin acts directly on the SOD enzyme was investigated by direct incubations of the tissues and the enzyme with the drug. 


\section{Materials and Methods}

\section{In Vivo Studies}

Male rats of the Wistar strain weighing 125-160 g were used. Control and experimental rats were matched by weight prior to the induction of diabetes via injection of streptozotocin (generous gift of Dr. Wm. E. Dulin, Upjohn Co., Kalamazoo, Mich.) in citrate buffer $(0.1 \mathrm{~mol} / \mathrm{l}, \mathrm{pH} 4.5)$. The dose of streptozotocin was $120 \mathrm{mg} /$ $\mathrm{kg}$ IP or $70 \mathrm{mg} / \mathrm{kg} \mathrm{IV}$. The animals were fasted 24 hours before the injection of streptozotocin and then fed (Wayne Lab-Blocks, Allied Mills, Inc.) ad lib. until sacrifice. Rats were usually killed 5 days after injection by decapitation with a guillotine (Harvard Apparatus Co., Dover, Mass.) unless stated otherwise. The concentration of glucose in the urine was estimated prior to sacrifice by glucose oxidase (Test-Tape, Eli Lilly and Co., Indianapolis, Ind.), and that of ketones with the nitropusside reaction (Acetest tablets, Ames Co., Div. Miles Lab., Elkart, Indiana).

Mixed arteriovenous blood was collected at sacrifice from severed vessels of the neck into heparinized tubes. Plasma glucose was measured by Autoanalyzer (Technicon Instruments Co., Tarrytown, N. Y.), using a method based on the reduction of ferricyanide; ketones in plasma were estimated with Acetest tablets. Urine and serum were usually negative or trace for ketones. Plasma ketones were not measured quantitatively in this study. In a different study in which rats of the same strain were treated with $120 \mathrm{mg} / \mathrm{kg}$ streptozotocin IP, the concentration of plasma $\beta$-hydroxybutyrate of diabetic rats 5 days post injection was $997 \pm$ $132 \mu \mathrm{mol} / 1(\mathrm{n}=12)$ and that of acetoacetate was $502 \pm 179 \mu \mathrm{mol} /$ $\mathrm{I}$; in control rats plasma $\beta$-hydroxy-butyrate was $142 \pm 21 \mu \mathrm{mol} / 1$ $(n=11)$ and acetoacetate was less than $100 \mu \mathrm{mol} / \mathrm{l}$ measured by enzymatic methods $[14,15]$. Mortality due to diabetes or streptozotocin in this time period was less than $10 \%$. Diabetic animals were included in the experiments only if the concentration of glucose in plasma was greater than $300 \mathrm{mg}$ per $100 \mathrm{ml}$ and if the animals either lost weight or gained less than $1 \mathrm{~g}$ per day. Previous studies from this laboratory [16] reported a weight gain of $6.75 \pm$ $0.28 \mathrm{~g} /$ day for 16 normal rats of the same strain and age.

In two experiments restoration of retinal SOD activity of diabetic rats by treatment with insulin was attempted. In the first experiment diabetic rats received two SC injections of 5 to $6 \mathrm{U}$ of regular insulin (40U Squibb, Princeton, N. J.), 18 and 4 hours before sacrifice on the fifth day after the streptozotocin injection. At sacrifice the mean plasma glucose of insulin treated rats was

Table 1. Superoxide dismutase activity in rat tissues

\begin{tabular}{|c|c|c|c|c|c|c|}
\hline \multirow{3}{*}{$\begin{array}{l}\text { Tissue } \\
\text { Aorta }\end{array}$} & \multirow{3}{*}{$\frac{\mathrm{n}}{8}$} & \multicolumn{4}{|c|}{ (SOD $\mu \mathrm{g} / \mathrm{g}$ protein) } & \multirow{3}{*}{$\frac{\mathrm{p}}{\mathrm{NS}}$} \\
\hline & & \multicolumn{2}{|c|}{ Control } & \multicolumn{2}{|c|}{ Diabetic } & \\
\hline & & 0.87 & \pm 0.24 & 0.70 & \pm 0.22 & \\
\hline Lung & 6 & 1.00 & \pm 0.06 & 0.90 & \pm 0.07 & NS \\
\hline Cerebrum & 6 & 2.23 & \pm 0.21 & 2.43 & \pm 0.10 & NS \\
\hline Liver & 7 & 43.0 & \pm 1.91 & 43.8 & \pm 2.11 & NS \\
\hline Kidney & 8 & 1.78 & \pm 0.21 & 1.80 & \pm 0.15 & NS \\
\hline Whole eye & 12 & 0.070 & \pm 0.01 & 0.082 & \pm 0.01 & NS \\
\hline Lens & 8 & 0.030 & \pm 0.003 & 0.030 & \pm 0.004 & NS \\
\hline Retina & 42 & 0.87 & \pm 0.05 & 0.61 & \pm 0.03 & $<0.001$ \\
\hline Retina $^{a}$ & 4 & 0.90 & \pm 0.06 & 0.60 & $\pm 0.04^{\mathrm{a}}$ & $<0.01$ \\
\hline Blood & 12 & 81.2 & \pm 5.1 & 51.3 & \pm 7.1 & $<0.001$ \\
\hline
\end{tabular}

a Tissue obtained from animals rendered diabetic with streptozotocin and then treated with insulin for three days

NS = not significant

$\mathrm{n}=$ number of tissue pairs assayed

Means \pm SEM are shown
$180-250 \mathrm{mg}$ per $100 \mathrm{ml}$ plasma while that of untreated diabetic rats exceeded $400 \mathrm{mg}$, and that of controls was $80-150 \mathrm{mg}$. In the second experiment therapy was started on the second day after the induction of diabetes and was continued until sacrifice on the fifth day. The initial dose was regular insulin SC $6 \mathrm{U} / 100 \mathrm{~g}$. Six hours later, NPH insulin $(3 \mathrm{U} / 100 \mathrm{~g})$ was administered, and treatment continued with twice daily injection of NPH insulin, supplemented with regular insulin when needed, the dose being adjusted to the glycosuria. After the first day of therapy most rats required $2 \mathrm{U}$ NPH insulin twice daily. On this regimen diabetic animals gained weight normally (approximately $6 \mathrm{~g} /$ day) but showed occasional glycosuria. Their mean plasma glucose at sacrifice was close to that of the normal fed rats (mean $121 \pm 15$ (SEM) mg per $100 \mathrm{ml}$; $\mathrm{n}=15$ ).

The brain, kidney, and liver were dissected and washed with saline to remove the blood. The lungs and aorta were perfused with saline before dissection. The eyes were enucleated, the posterior portion of the eye separated and the retina floated off in saline solution. Tissues were kept frozen for as long as two weeks until assay. The enzyme was tested for stability during storage and was found to be stable for two weeks in whole tissues but of variable stability as a homogenate.

For the time course studies, rats were injected IV or IP with varying doses of streptozotocin. Blood samples $(0.2 \mathrm{ml})$ were obtained by repeated cardiac puncture prior to the streptozotocin injection and at 1, 3, 5, 24, 48 and 72 hours. The heparinised samples were diluted $1: 10$ with distilled water, centrifuged $\left(500 \times \mathrm{xg}\right.$ at $\left.4^{\circ} \mathrm{C}\right)$ and the supernatants assayed for SOD activity and glucose content.

\section{In Vitro Studies}

Tissue samples $(0.1 \mathrm{ml}$ heparinised blood, or 2 retinas $)$ in $1.0 \mathrm{ml}$ phosphate buffer $(0.3 \mathrm{~mol} / \mathrm{l}, \mathrm{pH} 7.4)$ with and without streptozotocin $(0.2$ to $10 \mathrm{mg})$ were incubated for one hour at $37^{\circ} \mathrm{C}$. The samples were then frozen until assay. After thawing, samples were homogenised and treated as described below.

\section{Assay}

Protein concentration was estimated by the methods of Lowry et al. [17] or Bradford [18] using bovine albumin standards. Similar values were obtained by the two methods. The SOD activity measurement employed in this study is based on the ability of the enzyme to inhibit the reduction of nitroblue tetrazolium by superoxide radicals which are generated with xanthine oxidase [19]. Assay was performed in $0.05 \mathrm{~mol} / 1$ sodium carbonate, $\mathrm{pH} 10.2,10^{-4} \mathrm{~mol} / 1$ EDTA. The tissue samples were homogenized at $0-5^{\circ}$ for one minute with a Polytron tissue homogeniser in $1 \mathrm{ml}$ $0.5 \mathrm{~mol} / \mathrm{l}$ sodium phosphate, $\mathrm{pH} 7.4,10^{-4} \mathrm{~mol} / \mathrm{L}$ EDTA, using 1 to 4 retinas or $100 \mathrm{mg}$ of the other tissues per assay. Homogenates were centrifuged at $500 \mathrm{xg}$ for 10 minutes $\left(4^{\circ} \mathrm{C}\right)$ to pellet cell debris. The $3 \mathrm{ml}$ assay system typically contained nitroblue tetrazolium (Sigma, St. Louis, Mo.) $2.5 \times 10^{-5} \mathrm{~mol} / 1,25 \mu \mathrm{l}(7.6 \mathrm{mU})$ xanthine oxidase (Sigma, grade $1,10^{-3} \mathrm{U}$ ) and $25 \mu \mathrm{l}$ of the sample. The reduction of tetrazolium was measured spectrophotometrically at $560 \mathrm{~nm}$; triplicate values were obtained (reproducibility was $\pm 5 \%$ ) and the average used for calculations. The SOD content was estimated by comparison with an erythrocyte SOD standard (Truette Labs., Houston, Texas) and referred to protein content. Cyanide inhibition was measured by the addition of $10 \mathrm{mmol} / \mathrm{l} \mathrm{KCN}$ to the $3 \mathrm{ml}$ assay mixture [19]. Denaturation by heat was carried out by boiling the sample for one minute.

\section{Gels}

Disc electrophoresis was performed in polyacrylamide gels $(7.5 \mathrm{~g}$ per $100 \mathrm{ml}$ ) using the system described by Maurer [20] except that 


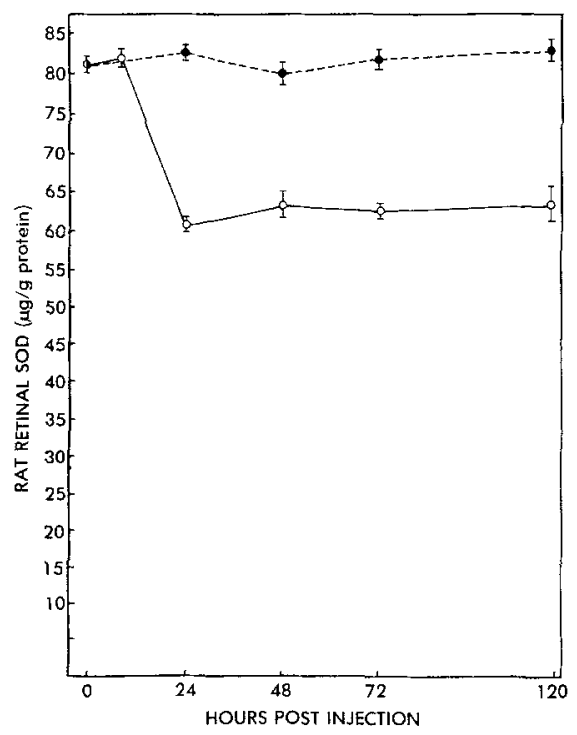

Fig. 1. Changes in retinal SOD activity in control rats

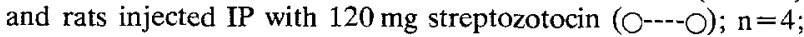
brackets represent SEM

stacking gels were not employed. Samples $(25-50 \mu \mathrm{l})$ were mixed with a crystal of bromophenol blue and sucrose $(10 \mathrm{mg} / \mathrm{ml})$. The gels were stained for SOD at $37^{\circ}$ for 1 hour in $0.2 \mathrm{~mol} / 1$ potassium phosphate, pH 8.0. Each $100 \mathrm{ml}$ of staining solution contained $8 \mathrm{mg}$ phenazine methosulphate (Sigma), $30 \mathrm{mg}$ nitroblue tetrazolium, $14 \mathrm{mg}$ hypoxanthine and $200 \mathrm{mU}$ of xanthine oxidase, (Buttermilk form) [13]. The gels were stained for protein with Coomassie brilliant blue according to the method of Weber and Osborn [21]. Pure bovine erythrocyte SOD was obtained from Truette Labs., Houston, Texas.

\section{Results}

Several tissues obtained from control rats and from diabetic rats five days after injection of streptozotocin were assayed for SOD activity (Table 1). The retinas and blood were the only tissues which showed a significant change in streptozotocin treated rats. A $30-40 \%$ decrease in enzyme activity was observed. Treatment with insulin for three days failed to affect the decreased SOD activity of the retina although plasma glucose levels at sacrifice were close to normal $(121 \pm 15 \mathrm{mg}$ per $100 \mathrm{ml}$ for treated diabetics, $>400$ for untreated diabetics).

In the retina, no change in SOD activity was observed within eight hours but a significant decrease was obtained twenty-four hours after the IP injection of $120 \mathrm{mg}$ streptozotocin/ $\mathrm{kg}$ (Fig. 1) and the level remained depressed for at least five days. Changes in SOD activity could be monitored more accurately in blood as each animal served as its own control. Following intraperitoneal injection of $120 \mathrm{mg}$ streptozotocin $/ \mathrm{kg}$ the decrease in enzyme activity

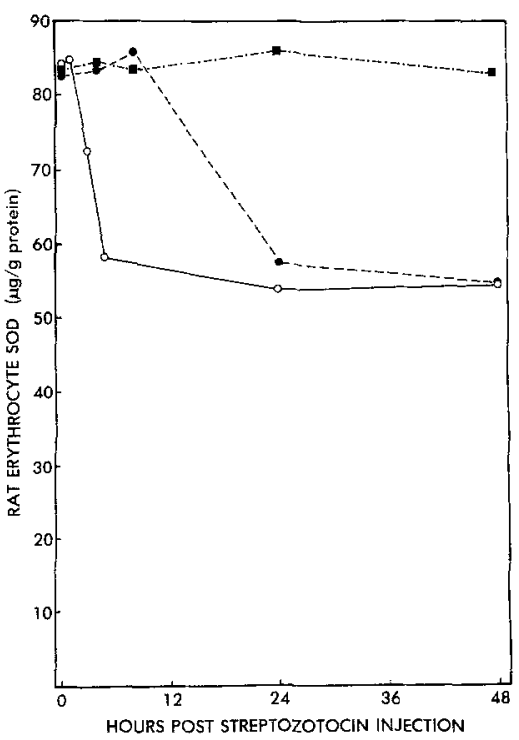

Fig. 2. Changes in rat erythrocyte SOD activity at various time intervals after the injection of $120 \mathrm{mg} / \mathrm{kg}$ streptozotocin IP (๑---), $\mathrm{n}=5 ; 70 \mathrm{mg} / \mathrm{kg}$ streptozotocin IV $\left(\mathrm{O}^{-\cdots} \mathrm{O}\right), \mathrm{n}=5$; and control $(\mathbf{\square}--\mathbf{0}) ; \mathrm{n}=6$; standard error for each point was less than \pm 8.5

observed paralleled that in the retina (Fig. 2). Following intravenous injection of $70 \mathrm{mg} / \mathrm{kg}$, a decrease in blood SOD activity was observed within four hours (Fig. 2).

Preliminary data on heparinised venous blood samples drawn one hour after a meal from five young adults with juvenile diabetes and elevated plasma glucose $(326 \pm 40 \mathrm{mg} / 100 \mathrm{ml})$ and six nondiabetic healthy volunteers of matched age and sex with normal plasma glucose were obtained. The diabetic patients had taken their usual dose of insulin. No correlation between plasma glucose levels and SOD activities was observed $(154 \pm 13 \mu \mathrm{g} \mathrm{SOD} / \mathrm{g}$ protein for diabetic patients and $150 \pm 10 \mu \mathrm{g} \mathrm{SOD} / \mathrm{g}$ protein for controls).

In order to establish if the observed decrease in SOD activity in streptozotocin-induced diabetic rats was an effect of the drug itself, tissues were incubated with the streptozotocin and SOD levels measured. Upon incubation for one hour at $37^{\circ} \mathrm{C}$ in the presence of streptozotocin, the SOD activity of the retinas and blood of the normal rats was decreased by approximately $30 \%$ (Table 2). Longer incubation resulted in no further reduction in enzyme activity. The minimum effective concentration of streptozotocin in vitro on incubation for 1 hour was $6 \mathrm{mg} / \mathrm{ml}$ blood (Table 3). No further decrease was observed with increased drug concentrations (Table 3). Pure SOD isolated from bovine erythrocytes also showed a decrease in activity of $30 \%$ after incubation with the drug. Blood from normal and diabetic hyperaemic humans showed a similar decrease in SOD 
Tabele 2. Effect of incubation with streptozotocin on superoxide dismutase activity

\begin{tabular}{|c|c|c|c|}
\hline \multirow[t]{2}{*}{ Tissue } & \multicolumn{2}{|c|}{$\operatorname{SOD}(\mu / \mathrm{g}$ protein $)$} & \multirow[t]{2}{*}{$\mathrm{p}$} \\
\hline & Control & Streptozotocin & \\
\hline Rat retinas & $0.85 \pm 0.05$ & $0.63 \pm 0.05$ & $<0.01$ \\
\hline Bovine retinas & $0.42 \pm 0.02$ & $0.32 \pm 0.02$ & $<0.01$ \\
\hline Rat blood & $81.2 \pm 5.2$ & $53.0 \pm 3.1$ & $<0.001$ \\
\hline Human blood & $151.5 \pm 10.1$ & $102.3 \pm 6.1$ & $<0.001$ \\
\hline
\end{tabular}

Tissues incubated with or without streptozotocin $(10 \mathrm{mg} / \mathrm{ml})$ at $37^{\circ}$ for one hour, means \pm SEM are shown; means represent at least six independent observations

Table 3. Effect of streptozotocin concentration on superoxide dismutase activity

\begin{tabular}{ll}
$\begin{array}{l}\text { Streptozotocin } \\
(\mathrm{mg} / \mathrm{ml} \text { Blood })\end{array}$ & $\begin{array}{l}\text { SOD } \\
(\mu \mathrm{g} / \mathrm{g} \text { protein })\end{array}$ \\
\hline 0 & $84 \pm 2$ \\
2 & $85 \pm 5$ \\
4 & $83 \pm 2$ \\
6 & $58 \pm 3$ \\
8 & $61 \pm 2$ \\
10 & $59 \pm 3$ \\
100 & $60 \pm 2$ \\
\hline
\end{tabular}

Tissues incubated with or without streptozotocin at $37^{\circ}$ for one hour. Means \pm SEM are shown, $n=3$

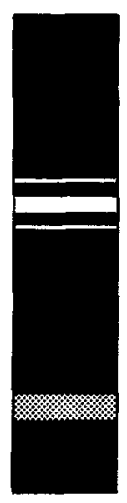

A
B

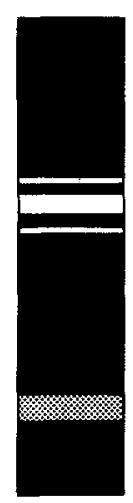

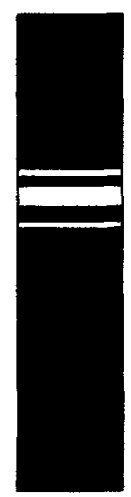

C

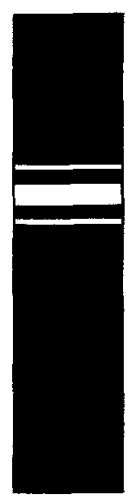

D
Fig. 3. Electrophoretic patterns of polyacrylamide disc gel electrophoresis of soluble superoxide dismutases: $\mathbf{A}$ Control rat retinal extract. B Diabetic rat retinal extract. C Control rat erythrocyte extract. D Diabetic rat erythrocyte extract. Gels were stained for SOD activity

activity upon incubation with streptozotocin $(10 \mathrm{mg} /$ $\mathrm{ml}$ blood) for 1 hour: samples from diabetics $(\mathrm{n}=3)$ decreased from $152 \pm 10 \mu \mathrm{g} \mathrm{SOD} / \mathrm{g}$ protein to $105 \pm$ $10 \mu \mathrm{g} \mathrm{SOD} / \mathrm{g}$ protein and control samples $(\mathrm{n}=3)$ from $146 \pm 8 \mu \mathrm{g} \mathrm{SOD} / \mathrm{g}$ protein to $100 \pm 10 \mu \mathrm{g}$ $\mathrm{SOD} / \mathrm{g}$ protein.

The main isozyme of retinal and erythrocyte SOD in diabetic and control rats demonstrated identical electrophoretic mobilities (Fig. 3). Somewhat fainter activity stains were obtained for the diabetic samples. The retinal samples contained a fast moving isozyme not present in the erythrocyte samples. No differences between enzymes from the diabetic and control animals were detected with respect to reaction with cyanide or denaturation by heat. Complete inactivation of all the SOD enzymes by both heat and cyanide was observed by failure of the enzyme to inhibit the NBT reduction and by the absence of any SOD activity on polyacrylamide gels.

\section{Discussion and Conclusions}

It is not clear why streptozotocin causes a decrease in SOD activity in the retina and blood but not in other tissues. The enzyme is found in most tissues of the body. Small differences $( \pm 10 \%)$ may not be detected by the assay system used and such differences in a particular tissue may be masked when the whole organ is assayed. For example, the retinal enzyme represents less than $10 \%$ of whole eye SOD activity [13]. Other ocular tissues may show no SOD variation; indeed, the lens enzyme was unaffected. No difference in enzyme level of the whole eye was observed between samples from diabetic and normal rats. It is possible, however, that SOD enzyme of the retina and the red blood cell, and maybe of some other tissues (e. g., the $\beta$-cells) which we have not yet examined, is particularly sensitive to the deleterious effect of streptozotocin due to some unique feature of the enzyme molecule or of the cellular structure.

Insulin treatment failed to restore the decreased SOD activity of the diabetic retinas in two separate experiments. This suggested that a drug effect was being observed rather than a primary effect due to the diabetic state. The direct action of the drug on the erythrocyte and retinal SOD was clearly demonstrated by the decrease in enzyme activity upon in vitro incubation with the drug. The dose level of drug required to produce the maximum in vivo effect was of the same order of magnitude as the level effective in vitro when an intravenous injection was used. This in vivo dose would result in an initial blood concentration of approximately $1 \mathrm{mg} / \mathrm{ml}$ which would rapidly fall as streptozotocin is degraded and taken up by the tissues. The lowest effective dose in vitro was $6 \mathrm{mg} / \mathrm{ml}$. However, in vitro incubations were only carried out for 1 hour. The in vivo effect was not detectable at 1 hour, but was evident at 4 hours after IV injection.

Qualitatively, the enzymes appeared to be identical by gel electrophoresis before and after drug treatment. The activity stain was somewhat lighter after 
drug treatment indicating a decrease in quantity, but no new isozymes were detected.

The in vitro streptozotocin effect on SOD activity is not species specific as it was observed in tissues from humans, rats and cows. The inhibition was of the same order of magnitude when either the purified enzyme or whole tissues were exposed to streptozotocin, suggesting that the drug affects the enzyme molecule directly.

SOD provides an important protective mechanism against damage by radicals which are present in any cell utilizing oxygen. Our findings are of possible therapeutic significance as patients with insulin producing tumours are administered streptozotocin as treatment. Furthermore, caution should be used in the interpretation of results obtained using animals rendered diabetic by streptozotocin. In view of our results and those of Slonim et al. [6], some enzyme abnormalities observed in such animals may be due to direct drug effects rather than a consequence of the diabetic state.

Acknowledgements. Support for this work was provided by grants from "Fight For Sight, Inc.", Sammy Davis, Jr. Fund, USPHS grant AMO2001 from the National Institute of Arthritis Metabolism and Digestive Disease, and USPHS grant EY01612 from the Eye Institute. We thank Deenie Peeler, Martha Heddon and Charlene Alford for technical help in certain experiments.

\section{References}

1. Junod, A., Lambert, A. E., Orci, L., Pictet, R., Gonet, A. E., Renold, A. E.: Studies of diabetogenic action of streptozotocin, Proc. Soc. Exp. Biol. Med. 126, 201-205 (1971)

2. Rerup, C. C.: Drugs producing diabetes through damage of the insulin secreting cells. Pharmacol. Rev. 22, 485--518 (1970)

3. Murray-Lyon, I. A., Cassar, J., Coulson, R., Williams, R., Ganguli, P. C., Edwards, J. C., Taylor, K. W.: Further studies on streptozotocin therapy for a multiple-hormone-producing islet cell carcinoma. Gut 12, 717-720 (1971)

4. Ho, C.-K., Hashim, S. A.: Pyridine nucleotide depletion in pancreatic islets associated with streptozotocin-induced diabetes. Diabetes 21, 789-793 (1972)

5. Hing, M., Katsilambros, N., Maier, V., Schatz, H., Pfeiffer, E. P.: Signifinance of streptozotocin induced nicotanamideadenine-dinuleotide (NAD) degradation in mouse pancreatic islets. FEBS Lett. 30, 225-228 (1973)

6. Slonim, A. E., Fletcher, T., Burker, N., Burr, I. M.: Effect of streptozötocin on red blood-cell-reduced glutathione: Modidication by glucose, nicotinamide and epinephrine. Diabetes 25, 216-222 (1976)

7. Fridovich, I.: Superoxide radical and superoxide dismutase. Acc. Chem. Res. 5, 321-326 (1972)
8. Heikkila, R., Cohen, G.: Inhibition of biogenetic amine uptake by hydrogen peroxide: A mechanism for toxic effects of 6-hydroxydopamine. Science 172, 1257-1258 (1971); Franzer, J.P., Thoenen, H.: Selective destruction of adrenergic nerve terminals by chemical analogues of 6-hydroxydopamine. Experienta 29, 314-315 (1973)

9. Cohen, G., Heikkila, R. E.: The generation of hydrogen peroxide, superoxide radical and hydroxyl radical by 6-hydroxydopamine, dialuric acid and related cytotoxic agents. J. Biol. Chem. 249, 2447-2452 (1974)

10. Chen, C. H., Patz, A.: Components of vitreous-soluble proteins: Effects of hyperoxia and age. Invest. Ophthalmol. 15, 228-232 (1976)

11. Fried, R., Mandel, P.: Superoxide dismutase of mammalian nervous system. J. Neurochem. 24, 433-438 (1975)

12. Hall, M. O., Hall, D. O. Superoxide dismutase of bovine and frog rod outer segments. Biochem. Biophys. Res. Commun. 67, 1199-1204 (1975)

13. Crouch, R., Priest, D. G., Duke, E.: Superoxide dismutase of bovine ocular tissues. (submitted for publication)

14. Williamson, D. N., Mellanby, J.: D-(-)-3-Hydroxybutyrate. In: H. V. Bergmeyer (ed.): Methods of Enzymatic Analysis, pp. 1836-1839. New York: Academic Press 1974

15. Mellanby, J., Williamson, D. N.: Acetoacetate. In: H. V. Bergmeyer (ed.): Methods of Enzymatic Analysis, pp. 1840-1843. New York: Academic Press 1974

16. Buse, M. G., Herlong, F., Weigard, D., Spicer, S. S.: The effect of diabetes, insulin and Wallerian degeneration on leucine metabolism of isolated rat sciatic nerves. J. Neurochem. 27, 1339-1345 (1976)

17. Lowry, O. H., Rosebrough, N. J., Farr, A. L., Randall, R. J.: Protein measurement with folin phenol reagent. J. Biol. Chem. 193, 265-275 (1951)

18. Bradford, M.: A rapid and sensitive method for the quantitation of microgram quantities of protein utilizing the principles of protein-dye binding. Anal. Biochem. 72, 248-254 (1976)

19. Beauchamp. C., Fridovich, I.: Superoxide dismutase: Improved assays and an assay applicable to acrylamide gels. Anal. Biochem. 44, 276-287 (1971)

20. Maurer, H. R.: Methods of Analytical Disc Electrophoresis. In: Disc Electrophoresis and Related Techniques of Polyacrylamide Gel Electrophoresis, pp. 32-82. New York: Walter de Gruyter 1971

21. Weber, K., Osborn, M.: The reliability of molecular weight determinations by dodecyl sulfate-polyacrylamide gel electrophoresis. J. Biol. Chem. 244, 4406-4412 (1969)

Received: October 24, 1977,

and in revised form: February 20, 1978

Dr. Rosalie Crouch

Departments of Biochemistry and Ophthalmology

Medical University of South Carolina

171 Ashley Avenue

Charleston, SC 29403

USA 